\title{
内航フェリーへの空気潤滑システムの適用と 実運航データに基づく実海域における省エネ効果検証
}

\author{
正会員 溝 上 宗 二* 正会員 黒 岩 良 太米 \\ Installation of Air Lubrication System for Ro-Pax Ferry and Verication of its Effect \\ in Actual Seas Based on Onboard Measurement Data \\ by Shuji Mizokami, Member $\quad$ Ryota Kuroiwa, Member
}

\begin{abstract}
Summary
The authors verified an energy saving effect of an air lubrication system for the domestic service ferry which was one of slender body ships. The energy saving effect was evaluated by the engine output reduction rate of system ON and OFF at speed-trial test. As the result, a net energy saving effect of about $3.7 \%$ was confirmed.

After that, long-term voyage monitoring had been conducted since the ship was in service. At the same time, monitoring had been conducted about same type of sister ship without air lubrication system, in service on the same route.

The investigation result of the energy saving effect by comparison of fuel consumption of both ships, a net effect of about $3.13 \%$ was confirmed. According to these results, the effectiveness of an air lubrication system for slender body ships was proved; therefore, scope of an air lubrication system as energy saving system of ships had expanded.
\end{abstract}

\section{1. 緒 言}

地球温暖化対策として，国際海運業界においても GHG(温 暖化ガス) 排出削減の取り組みは喫緊の課題であり, 2013 年 から新造船に対する燃費規制が開始されている。この燃費規制 は，エネルギー効率設計指針（EEDI）が基準值以下であるこ とを要求するものであり, この基準值は段階的に強化されるこ とになっている。

船舶から排出される GHG はそのほとんどが二酸化炭素 $\left(\mathrm{CO}_{2}\right)$ であり, 大部分が燃料燃焼に起因するものである。し たがって, GHG 排出を抑える手段は, 燃料消費量を削減する ことに帰着する。燃費を改善する手段としては, 例えば, 推 進性能に優れた船型及び推進機の開発, 及びリアクションフィ ン等の省エネデバイスによる性能改善, 他には推進抵抗の大部 分を占める船体の摩擦抵抗を減少させる低摩擦塗料の採用等が 挙げられる。また，近年では空気を利用した船体摩擦抵抗低減 についても, 研究開発が国内外で活発に進められている。

初めて空気を用いた実験が行われたのは, 1973 年の McComick, Bhattacharyya $^{1)}$ による研究例が挙げられる。実験 の結果, 気泡による抵抗減少が確認されたことにより, その後,

* 三菱造船 (株) マリンエンジニアリングセンター 開発部 ** 三菱重工業 (株) 総合研究所 流体第一研究室

原稿受理 平成 30 年 11 月 28 日
国内外で基礎研究並びに開発研究が盛んに行わた 2)3)4)5)。し かし, 実験室での模型試験では, フルード則に基づいて気泡径 の相似性を満たすことが難しく, 実機サイズでの効果を確認す ることが出来なかったため, 2000 年代に入ると実用化を目的 とした実船実験の段階に移り, 国内では産学のプロジェクト が実施された 6)7)899)。これらの取り組みにおいて, 抵抗低減 効果を効率的に得るための空気の供給方法や吹き出し方法の 検討が進められ, 児玉らの ${ }^{9)}$ のセメント運搬船を用いた実船 実験では，4〜5\%の正味省エネ効果が確認されたことにより， 空気潤滑法による燃料消費削減の可能性が拓かれた。

著者らは，環境対策を背景とした省エネ技術開発の一環とし て, モジュール運搬船を対象に空気潤滑システム (Mitsubishi Air Lubrication System ; MALS) を恒久設備として実船搭 載し, 海上運転において約 $10 \%$ の省エネ効果を実証している 10)。この実船試験では, 空気で船底を満遍なく覆うことで摩 擦抵抗を計画したレベルまで減少させることが出来ていたが, 対象としたモジュール運搬船の船型は幅広で浅喫水という特徵 を持ち, 船底の平坦部が大きく空気潤滑に適した船であったた め, この結果をもってあらゆる船種・船型に対して十分な効果 を与えるものと判断するには至っていない。

今後, 空気潤滑システムを様々な船型の船舶に適用するため には, いくつかの解決すべき課題が残されており, 特に, フェ リー, RORO 船, PCC, コンテナ船等の瘦せ型船や, VLCC, バルクキャリアー等の大型で喫水が大きい船については, 更な る実船試験による検証が必要である。そこで, 前者の課題解 
決を目的として，瘦せ型船に分類される内航フェリーを対象 に空気潤滑システムを搭載し，省エネ効果の検証を実施した。 本論文ではその結果について報告する。

本研究においては, 省エネ効果の検証に際して 2 通りの方 法で検討を行った。まず，海上試運転時に速力確認試験の要領 に基づいて, 空気潤滑システムを作動状態と非作動状態に切り 替えて航走し, 両状態の船速と主機出力の解析結果から省エネ 効果を確認した。

次に，本船の就航後に長期間の運航モニタリングを実施す ると同時に, 同一航路に就航している空気潤滑システムを搭載 していない同型姉妹船についても運航モニタリングを行って, 両船の運航データの解析結果を比較することで省エネ効果を評 価した。

\section{2. 搭載船と空気潤滑システム}

\section{1 供試船の概要}

2012 年 9 月に就航したマルエーフェリー株式会社殿所有の “フェリー波之上”を供試船として空気潤滑システムを搭載し, 空気潤滑効果の検証を実施した。Fig.1 に本船の航走写真を， Table 1 に本船の主要目を示す。

本船は, 鹿児島〜奄美群島〜沖縄航路に就航している。寄港 地は鹿児島 (鹿児島新港), 奄美大島 (名瀬), 徳之島 (亀徳), 沖永良部 (和泊)，与論島 (与論)，沖縄本島 (本部及び那覇) であり，鹿児島と沖縄間を約 25 時間かけて運航している。

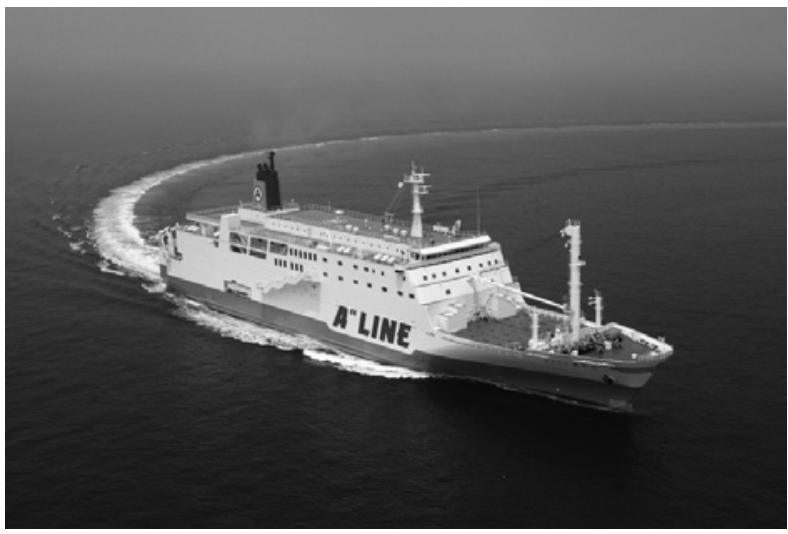

Fig. 1 "Ferry NAMINOUE" 8,072GT cargopassenger ship and car ferry

\section{2 搭載した空気潤滑システムの概要}

船底に配置した空気吹き出し口は，先行したモジュール運 搬船に対する空気潤滑システムの設計要領を参考に, 船首寄 りの位置には船体中心部に 1 ヶ所, 中央部寄りの位置には左 右舷 2 ヶ所に分けて吹き出し口を設けた。吹き出した空気は, 船体の周りを流れる海水と接触して乱れを生じ，その後分裂し て気泡流を形成し船体表面近傍を船尾に向かって流れ去る。

空気供給は, 車両甲板の一つ下の甲板にブロワー等の機器 を設置し, 船外から取り込んだ空気を圧縮して, 船底の各吹き
Table 1 Principal particulars of "Ferry NAMINOUE"

\begin{tabular}{|l|c||l|}
\hline Length & $L_{\mathrm{Oa}}$ & $145 \mathrm{~m}$ \\
\hline Breadth & $B$ & $24 \mathrm{~m}$ \\
Depth & $D$ & $14.5 \mathrm{~m}$ \\
Full load draft & $d_{\mathrm{mld}}$ & $6.25 \mathrm{~m}$ \\
\hline Gross tonnage & $G T$ & $8,072 \mathrm{t}$ \\
Main Engine & - & JFE $12 \mathrm{PC} 2-6 \mathrm{~V} \times 2$ \\
& & MR: $6,070 \mathrm{~kW} \times 2$ \\
Propeller & - & CPP-4blade \\
Speed & $U$ & 21.0 knots \\
\hline
\end{tabular}

出しチャンバーへ送り込んでいる。Fig.2 にブロワの設置状況 を示す。

効率的な空気潤滑効果を得るためには，船底から空気を均 一に吹き出すことが重要であり, 各配管に取り付けたオリフィ スで配管の空気流量調整を行った。オリフィス径は，1 次元熱 流体管路網解析ソフト (MelTHERFY) を用いてオリフィスの 圧損を調整し，出口流量が均等になるように決定した。管路網 のモデル化の範囲は，ブロワーから吹出しチャンバーへ接続す る配管出口 (チャンバー入り口直前) とした。モデルの境界条 件として, 入り口条件は吹き出し空気の設定流量を固定值とし て与え, 出口条件は圧力一定とし, 吹き出し位置における静水 圧を与えた。

吹き出し空気量は，空気潤滑制御システムで調整され，設 定した目標空気量と実流量の差が制御不感帯内に収束するよう にブロワ回転数を自動制御している。

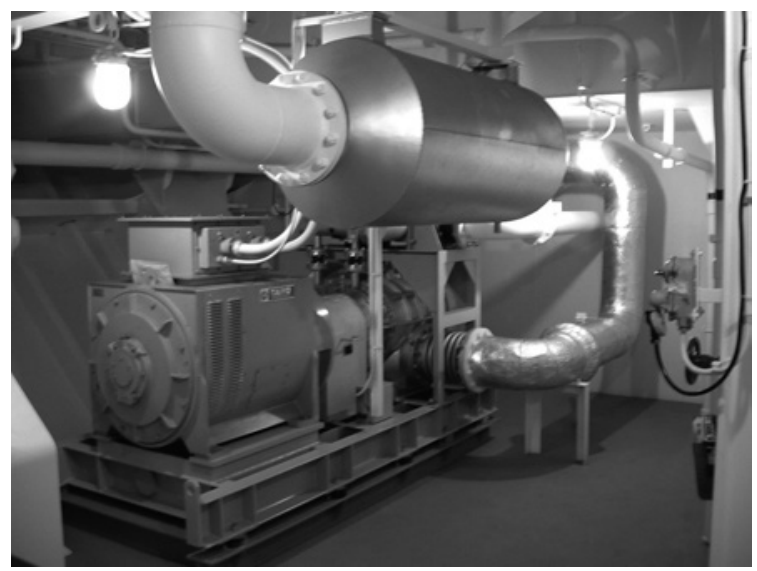

Fig. 2 Blower for air lubrication system

\section{3 省エネ効果推定}

まず，空気吹き出し口と Bottom Touching Line で囲まれ る船底の平坦な部分が空気で覆われるとすると, 本船では浸水 面積の $10 \%$ の面積が気泡で覆われることになる。そして，気 泡で覆われた部分の摩擦抵抗が半減するように, 相当空気厚さ 
$7 \mathrm{~mm}$ となる空気量を吹き出した場合, 船速 $20 \mathrm{knot}\left(V_{s}\right)$ で評 価して $3.6 \%$ 主機出力 $(\mathrm{BHP})$ 減少効果が見込まれる。

ただし，実船では Bottom Touching Line を外れて，船体 傾斜部を流れる気泡による摩擦抵抗低減効果が付加される可能 性があり，実船試験では，3.6\%よりも大きな効果が得られる ことも考えられる。

傾斜部を流れる気泡については，その摩擦抵抗低減効果を 明確に説明する知見がなく, CFD で傾斜部を含む被泡面積を 計算して, 推定した省エネ効果の妥当性を評価することが出来 ない。したがって, 実船試験においてその効果の影響を確認す るとともに, 今後の設計にフィードバックし推定精度の向上を 図る。

\section{3. 海上運転における省エネ効果の確認}

\section{1 省エネ効果確認試験}

空気潤滑システムの効果確認は, Fig.3 に示すように，通常 の海上公試で行う速力馬力確認試験 (Speed and Power trial run) に準拠して, 同一航路を一往復して, 船速及び主機出力 等を計測した。往路と復路で空気潤滑システムが OFF と ON の状態に対して計測を行い, システムの OFF/ON 切り替え時 には出力值が十分に静定する航走時間を設けた。この時, 主 機出力は軸馬力計で, 船速は DGPS を用いて計測した。なお, 就航状態における省エネ効果を確認するためバラスト水を張っ て, 試験時の喫水を本船運航状態に近い $5.96 \mathrm{~m}$ (even keel) と して海上運転を実施した。

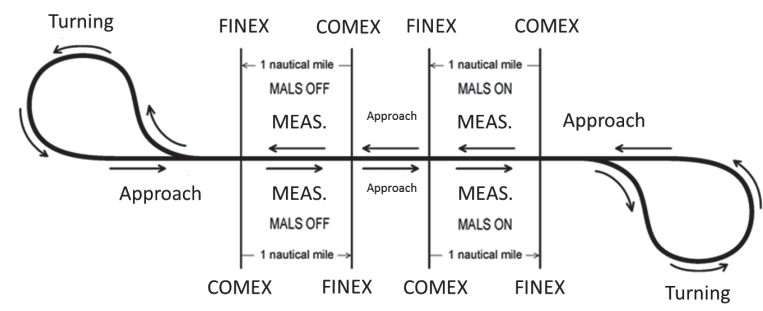

Fig. 3 Path of ship during typical speed/power maneuver

海上公試前の試走時に撮影した空気潤滑システム (MALS) が, OFF と ON の場合の航跡を比較して, Fig.4 に示す。空 気吹き出し時の航跡は, 船尾に到達した気泡により濃くなって いる事がわかる。

速力確認試験は主機出力 50\%，75\%，90\%の 3 状態で実施 し, 計測結果に風潮影響修正を施した。空気潤滑システム OFF とONについてそれぞれの船速-馬力曲線を作成し, 主機馬 力低減効果を求めた。Fig.5 に船速-馬力曲線を示す。試験は 波高 2.5〜3m の悪条件の下で実施されたが, 約 5.7\%の主機出 力低減効果が確認された。また, 試験を行った範囲では省エネ 効果に対する速度影響は本船に関しては小さい結果となって いる。川島ら 11) は, $50 \mathrm{~m}$ 長尺平板模型船を用いて，12，13， $15 \mathrm{knot}$ の 3 種類の曳航速度で実験を行い, 模型船の曳航速度

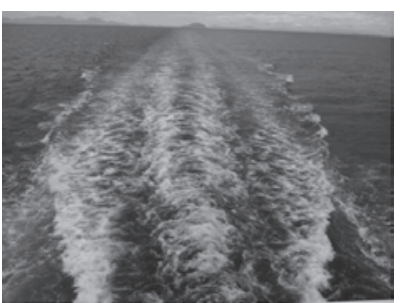

MALS OFF

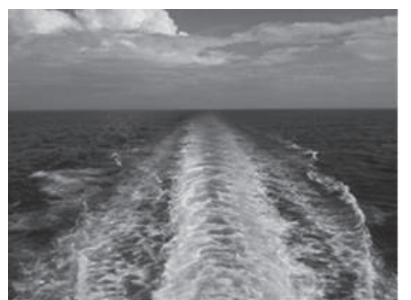

MALS ON
Fig. 4 Comparison of wakes

が上昇すると, 同じ相当空気厚さに対して抵抗低減率が小さく なっていることを報告している。本船の営業航海の速度域から 外れるが，より低速域で航行する場合は省エネ効果が大きくな る可能性がある。

速力確認試験時のブロワーの消費電力は, 主機出力の約 $2.0 \%$ 相当であったため, これを差し引くと正味省エネ効果 (Net) は約 $3.7 \%$ 程度となった。これは，4.1 節にて後述する ように，主機に NOx 排出規制強化の対策を施したことによる 燃費増加分を補うことができるレベルである。

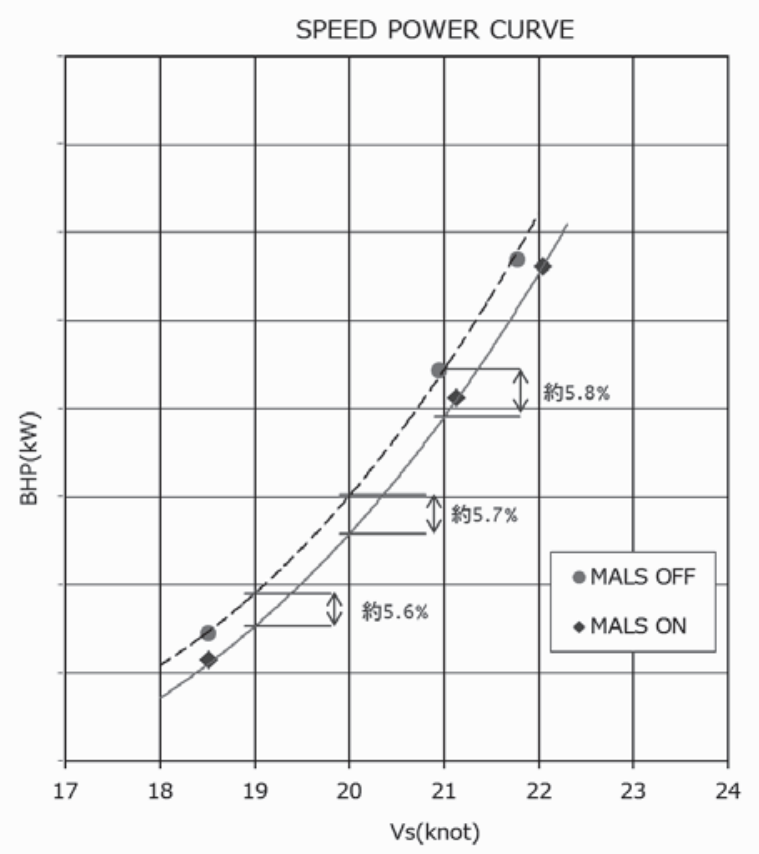

Fig. 5 Speed-Power curves for verification of power savings

\section{2 プロペラ変動圧及び振動計測}

速力確認試験と同時にプロペラ直上の変動圧計測と主船体 (3 甲板の船尾端 1 点) および居室 (4 点) の振動加速度計測を 実施した。プロペラ変動圧はプロペラ直上の船底外板 5 ケ所に 圧力変換器を取り付け一次成分の平均值を求めた。

空気潤滑システム OFF に対するプロペラ変動圧力増加率を Fig.6 に示す。先行研究 ${ }^{12) 13)}$ に述べられているように, プロ 
ペラディスク面に気泡が流入するとプロペラ変動圧が増加して いる。本船においても，プロペラ翼面への気泡流入が起きてい たと推測され，プロペラ変動圧力増加率は出力 (船速) の大き さに関わらず, 約 1.4 倍増加していた。

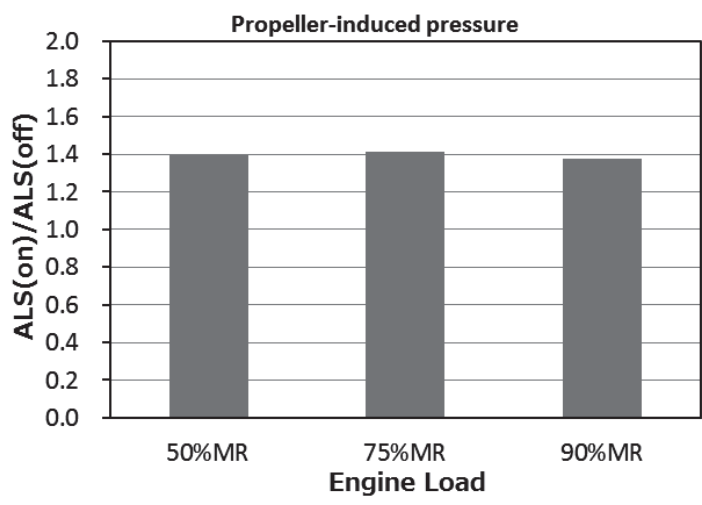

Fig. 6 Propeller-induced pressure increase ratio of MALS ON to OFF

空気潤滑システム OFF に対する船体振動増加率を, Fig.7 に示す。計測場所は， 5 甲板船尾側の二等和室である。プロ ペラへの気泡流入によりプロペラ変動圧が増加し，起振力の 増大に伴い船体振動の増加が懸念されたが，振動計測の結果 を見ると MALS ON の方が概ね低減している。さらに，全 出力状態において全ての計測点で ISO ガイドラインの Lower $\operatorname{Limit}(4 \mathrm{~mm} / \mathrm{s})$ を十分満足しており, 空気潤滑による船体振動 への悪影響は認められなかった。

空気潤滑により船体振動が低減するメカニズムは明確では なく，また省エネシステムとしての副次的効果ではあるが，特 に客船やフェリーなど乗客を運ぶ船舶に対しては，振動低減は 大きなメリットである。

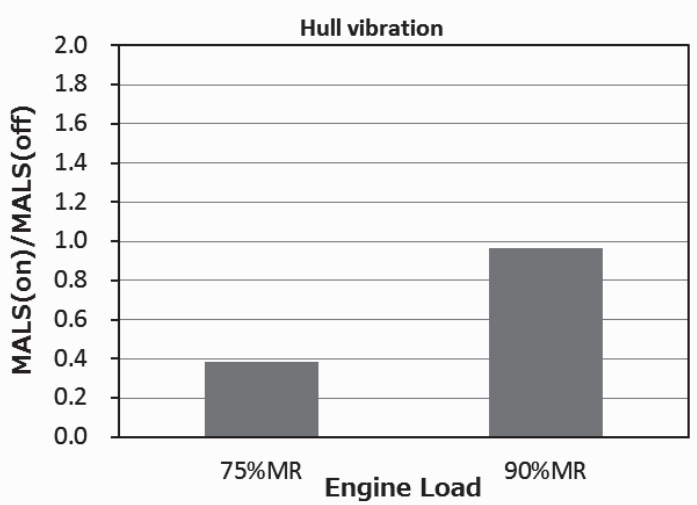

Fig. 7 Hull vibration increase ratio of MALS ON to $\mathrm{OFF}$

\section{4. 運航モニタリングによる実運航時の省エネ効果確認}

\section{1 省エネ効果の評価方法}

実運航時の省エネ効果を, 海上運転時に実施する速力確認 試験と同じ手順によって確認することは，運航スケジュール管 理の妨げとなり現実的に不可能である。一方，航海中に空気潤 滑システムの作動状態を ON と OFFに切り替えて計測した データを解析してみると, 解析結果のばらつきが大きく効果を 確認することが出来なかった。このばらつきは遭遇海象による 外乱影響と考えられるが，その補正は困難であり正しい評価が 行われているとは言い難い。加えて, 空気潤滑効果はシステム ON と OFF の推進抵抗の差を評価するため, 船体抵抗よりも 1 桁から 2 桁小さな量を扱うことになり，ばらつきが顕著であ れば精度の管理と保証が難しい。

本船“フェリー波之上”は，2008 年 7 月に就航した“フェ リーあけぼの”と同型姉妹船であり，同一航路を 2 隻で 2 日に 1 便運航している。また，“フェリーあけぼの”は空気潤滑シス テムを搭載していない。そこで，本論文では両船の運航モニタ リングを実施し，“フェリーあけぼの”の計測データを空気潤 滑システム OFF の場合と見做して，“フェリー波之上”で取 得した空気潤滑システム ON のデータと合わせて解析し，両 船の結果を比較することで実運航時の省エネ効果を検証した。

この検証方法は，両船の運航スケジュールが上り便と下り 便に別れているため，運航データを同一地点，同時刻に計測で きないことが課題である。そこで本論文では，その対策とし て長期間の運航モニタリングによりデータの母数を増やして, 計測データを解析することにより海象変動等の外乱影響を平滑 化した。

なお，“フェリー波之上” は，IMO NOx 規制 (TIER II) の 対策が行われており，“フェリーあけぼの”に対して主機関の 燃費が約 $3 \%$ 悪化している。両船の主機関の陸上試験結果を Fig. 8 に示す。

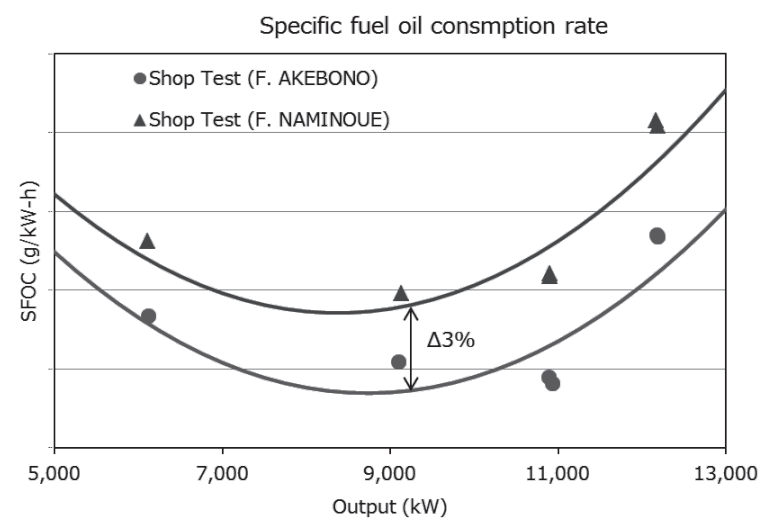

Fig. 8 Comparison of specific fuel oil consumption

\section{2 運航モニタリングデータ解析と評価}

“フェリー波之上”と“フェリーあけぼの”は，内航旅客船 の規則に従って，毎年入渠して検査を実施している。入渠時期 
は“フェリー波之上”が 9 月，“フェリーあけぼの”が 6 月を 基準に調整している。

航海中の運航データを，本船に搭載した運航モニタリング システムで自動収録し，20 秒毎に平均值を計算し CSV ファ イルの形式で記録しており，入渠検査時にモニタリングデータ を回収し解析を行った。

本船は寄港地が多いので, 寄港地間の航路毎に下り便（南 航）と上り便（北航）に分けて解析を実施した。Table 2 に各 航路の運航スケジュールを示す。鹿児島と沖縄間を運航する に際して, 鹿児島一名瀬航路が航海時間全体の約半分を占めて いる。

航路の列に括弧で併記した文字は航路の略称で, 以降に示 す図の凡例等に使用する。

Table 2 Voyage schedule from Kagoshima to Okinawa

\begin{tabular}{|c|c|c|}
\hline 航路 (下り) & 航路 (上り) & $\begin{array}{c}\text { 航海時間 } \\
\text { (分) }\end{array}$ \\
\hline 鹿児島 $\Rightarrow$ 名瀬 (KND) & 名瀬 $\Rightarrow$ 鹿児島 (NKU) & 660 \\
\hline 名瀬＝亀徳 (NKD) & 亀徳＝名瀬（KNU） & 200 \\
\hline 亀徳 $\Rightarrow$ 和泊 (KWD) & 和泊 $\Rightarrow$ 亀徳 (WKU) & 110 \\
\hline 和泊 $\Rightarrow$ 与論 (WYD) & 与論 $\Rightarrow$ 和泊 $(\mathrm{YWU})$ & 100 \\
\hline 与論 $\Rightarrow$ 本部 (YMD) & 本部 $\Rightarrow$ 与論 $(\mathrm{MYU})$ & 150 \\
\hline 本部 $\Rightarrow$ 那覇 $(\mathrm{MND})$ & 那覇 $\Rightarrow$ 本部 (NMU) & 110 \\
\hline
\end{tabular}

\section{(1) 解析対象データ}

“フェリー波之上”が 2012 年 9 月に就航して以降，2016 年 6 月までに計測したモニタリングデータを解析対象とした。モ ニタリング装置の不調等によるデータ取得の不具合を除くと, “フェリー波之上”で 657 航海, “フェリーあけぼの”で 499 航 海分のデータがサンプリングされた。

船が加減速している状態及び空気潤滑システムが OFFに なる出入港時の計測データを, 船速と主機回転数を閾值とし て除外し, 定常航行している範囲を解析対象とした。そして, 20 秒平均の計測データから航路間の平均を計算し解析データ とした。

\section{(2) 解析方法}

実運航時の解析は, 4.1 節に記載したとおり, 空気潤滑シス テムを搭載していない姉妹船 “フェリーあけぼの”を比較対象 とした。

“フェリー波之上”の鹿児島一名瀬航路のモニタリングデー タより, 船速 $V_{s}(\mathrm{knot})$ と無次元化した主機出力 $B H P$ の計測 結果を Fig.9 に示す。主機出力の無次元化は, 鹿児島一名瀬の 往復平均の主機出力を用いている。

図に示すように, 船速と主機出力の相関係数は 0.328 であ り両者の相関は小さいことがわかる。実航海時は, 波浪などの 遭遇海象による船速の変動が大きいことが要因であると考え
られ，計測值をそのまま評価検討に用いるのは望ましくない。 よって, 計測值に対して外乱影響を修正して船速の変動を除去 する必要があるが，波浪情報が不明であるため十分な補正が出 来なかった。

そこで，船速に変えてプロペラ速度 $V_{p 0}(\mathrm{~m} / \mathrm{sec})$ と主機出力 (無次元) の相関を調べてみると, Fig.10に示すように，相関 係数が 0.82 であり，両者には強い正の相関が確認された。こ こで，プロペラ速度は (1) 式で定義され，スリップをゼロとし た場合のプロペラ前進速度に相当する。

$$
V_{p 0}=P_{p} N_{p}
$$

ここに, $P_{p}\left(=0.7 \pi D_{p} \tan \phi\right)$ はプロペラピッチ $(\mathrm{m}), N_{p}$ はプ ロペラ回転数 $(\mathrm{rps}), D_{p}$ はプロペラ直径 $(\mathrm{m}), \phi$ は $0.7 \mathrm{R}$ にお けるプロペラ翼角 $(\mathrm{rad})$ を表している。

本船のプロペラ $(\mathrm{CPP})$ は, コンビネータ制御により, コン ピュータを介して翼角と主機回転数を制御しており, 設定した 回転数以上ではピッチ一定 - 回転数変化の制御となる。解析対 象のデータは通常航海時のデータであり, 大半が設定回転数以 上で運航されているので, 回転数と主機出力はほぼ舶用特性に 沿って変化している。したがって, 外乱影響をほとんど受けず にプロペラ速度と主機出力の相関が強いものと考えられる。

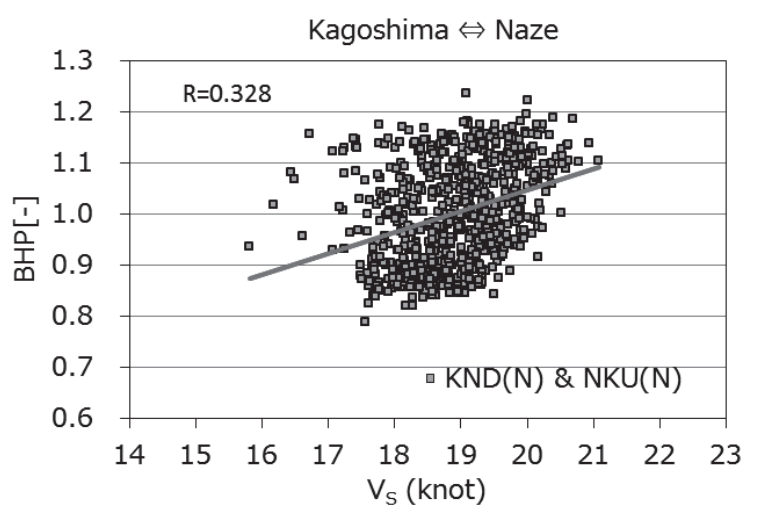

Fig. 9 Correlation of ship speed and BHP (Kagoshima-Naze Route)

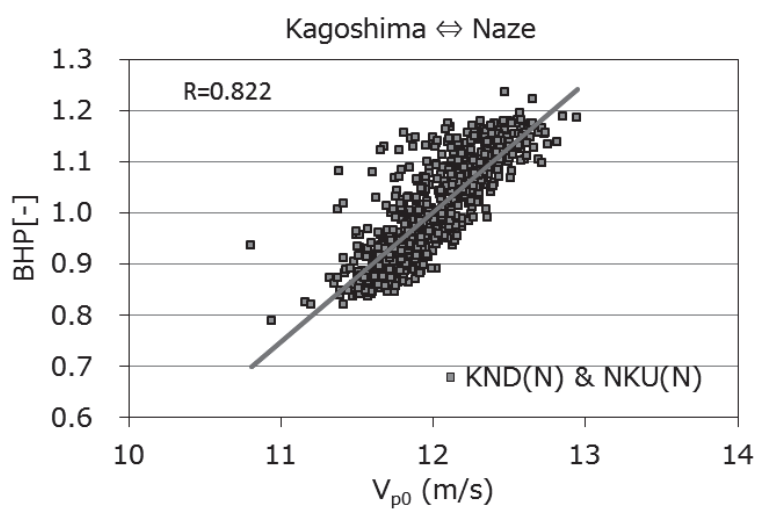

Fig. 10 Correlation of propller speed and BHP (Kagoshima-Naze Route) 
続いて，同じく鹿児島一名瀬航路のデータを対象に，燃料消 費量と主機出力の関係を Fig. 11 に示す。ここに, 燃料消費量, 主機出力共にそれぞれの平均值で無次元化して表示している。

両者の相関関係を求めると $\mathrm{R}=0.996$ であり大きな正の相関 が認められる。したがって, 運航モニタリングデータを用いた 解析においては, プロペラ速度と燃料消費量の関係に着目して 空気潤滑システムの省エネ効果を評価することとした。

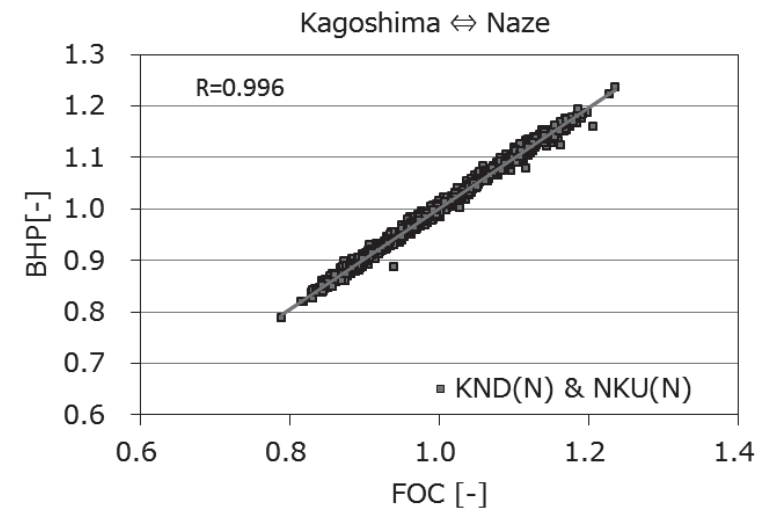

Fig. 11 Comparison between fuel consumption and engine output

(3) プロペラ速度と燃料消費量

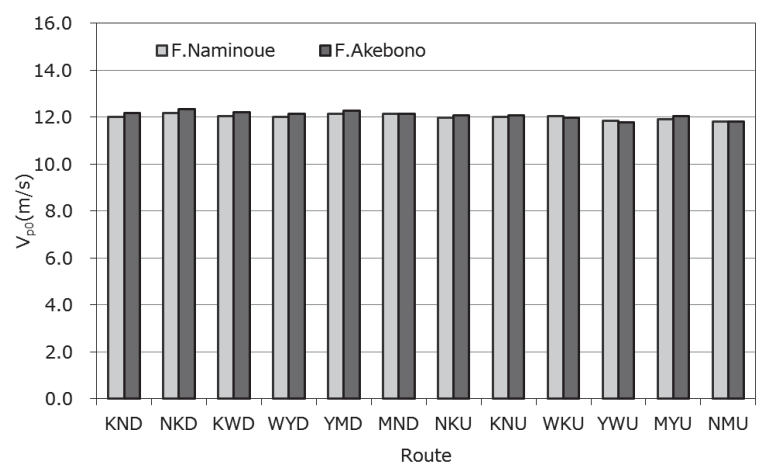

Fig. 12 Comparison of mean propeller speed between "F. Naminoue" and "F. Akebono"

各航路で “フェリー波之上”と“フェリーあけぼの”のプロ ペラ速度の平均值を求めて, Fig.12に比較して示す。眓より 両船のプロペラ速度は，ほぼ同等であることがわかる。航路と 運航ダイヤが同一なので, 両船は平均的に同じ負荷 (回転数) 指示で運航していることから, 燃料消費量の比較により省エネ 効果を評価することが可能であると考える。

Fig.13 から Fig.18 に, 航路別にプロペラ速度 $V_{p 0}$ と時間当 りの燃料消費量 FOC の実績を示す。燃料消費量は, 両船舶 の上りと下り別に求めた平均值で無次元化して表記している。 凡例の航路表示の $(\mathrm{N})$ は “フェリー波之上”を, (A) は “フェ リーあけぼの”のモニタリングデータを示す。

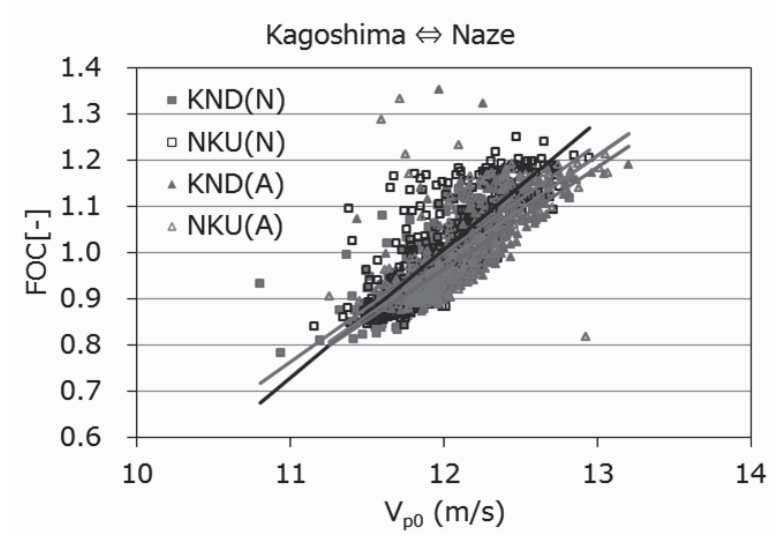

Fig. 13 Correlation of propller speed and fuel oil consumption (Kagoshima-Naze Route)

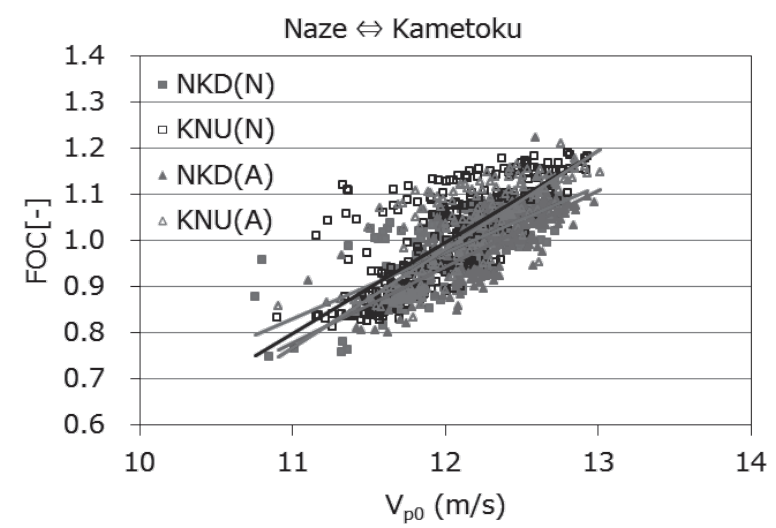

Fig. 14 Correlation of propller speed and fuel oil consumption (Naze-Kametoku Route)

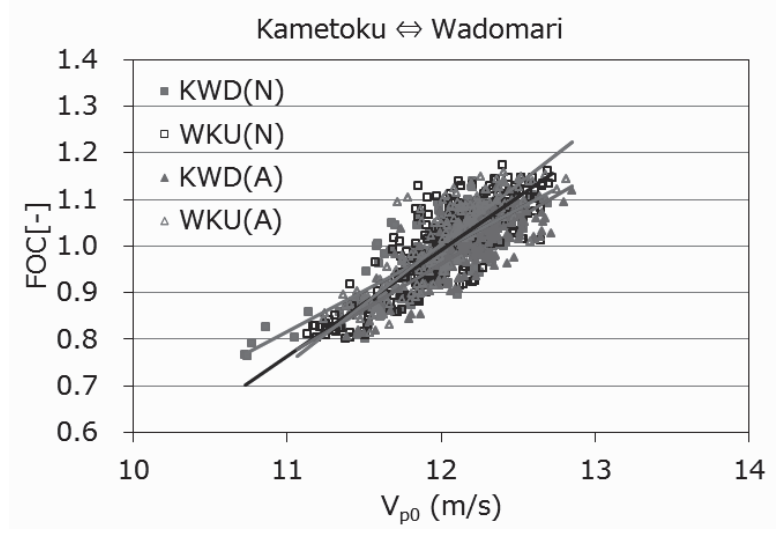

Fig. 15 Correlation of propller speed and fuel oil consumption (Kametoku-Wadomari Route)

図中に各航海毎の一次近似直線を示している。4. 2 項 (2) に おいて, プロペラ速度と燃料消費量の間には強い線形相関があ ることが分かっており，解析対象のプロペラ速度の範囲におい て，(2) 式に示す一次関数で表すことが出来る。航路毎に求め た一次近似式の傾き $a$ と切片 $b$ を, Table 3 に示す。 


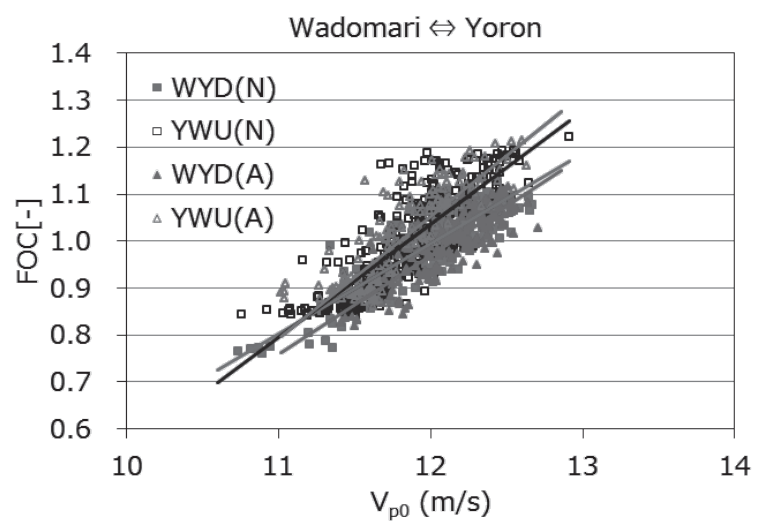

Fig. 16 Correlation of propller speed and fuel oil consumption (Wadomari-Yoron Route)

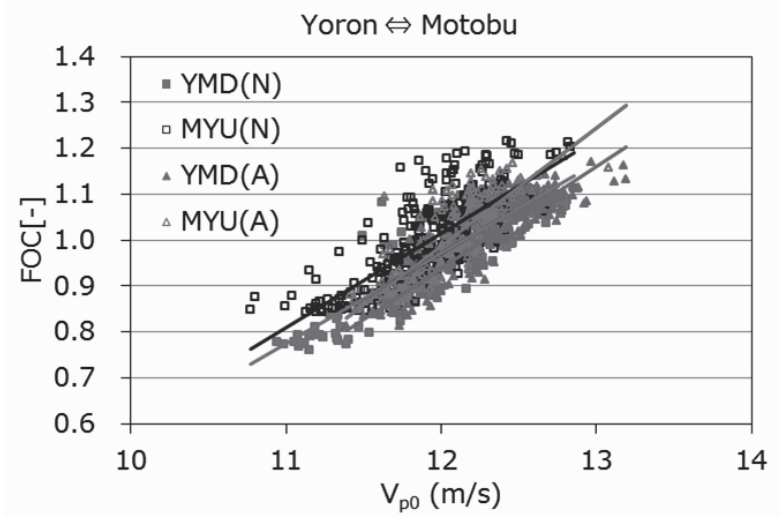

Fig. 17 Correlation of propller speed and fuel oil consumption (Yoron-Motobu Route)

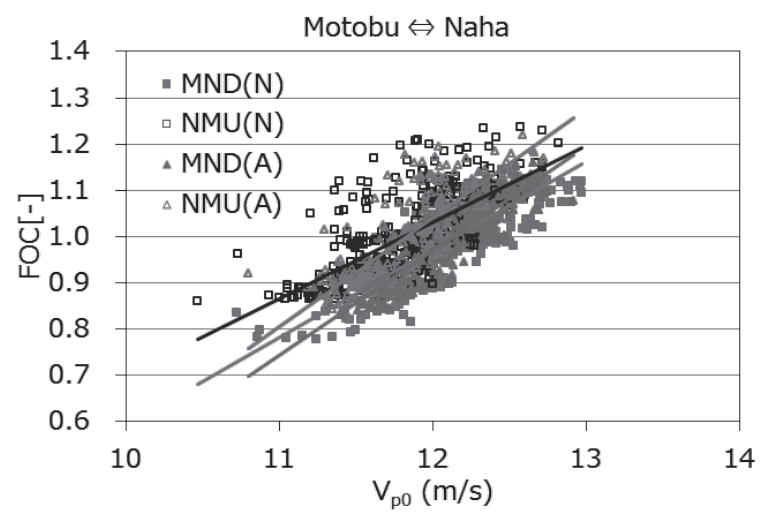

Fig. 18 Correlation of propller speed and fuel oil consumption (Motobu-Naha Route)

$$
F O C=a V_{p 0}+b
$$

\section{(4) 主機関の燃料消費量比較による省エネ効果の評価}

空気潤滑効果により船体に作用する摩擦抵抗が減少し, 推 進抵抗が小さくなると主機関の燃料消費量が減少するので,
Table 3 Approximation coefficient of fuel oil consumption $\left(F O C=a V_{p 0}+b\right)$

\begin{tabular}{|c|c|c|c|c|}
\hline \multirow[t]{2}{*}{ 航路 } & \multicolumn{2}{|c|}{ フェリー波之上 } & \multicolumn{2}{|c|}{ フェリーあけぼの } \\
\hline & $\mathrm{a}$ & $\mathrm{b}$ & $\mathrm{a}$ & $\mathrm{b}$ \\
\hline 鹿児島 $\Rightarrow$ 名瀬 (KND) & 0.410 & -3.185 & 0.399 & -3.037 \\
\hline 名瀬＝亀徳 (NKD) & 0.260 & -1.352 & 0.318 & -2.007 \\
\hline 亀徳 $\Rightarrow$ 和泊 (KWD) & 0.313 & -1.993 & 0.366 & -2.581 \\
\hline 和泊 $\Rightarrow$ 与論 (WYD) & 0.335 & -2.280 & 0.389 & -2.878 \\
\hline 与論 $\Rightarrow$ 本部 (YMD) & 0.347 & -2.451 & 0.413 & -3.208 \\
\hline 本部 $\Rightarrow$ 那覇 (MND) & 0.329 & -2.267 & 0.405 & -3.119 \\
\hline 名瀬 $\Rightarrow$ 鹿児島 (NKU) & 0.472 & -3.948 & 0.413 & -3.208 \\
\hline 亀徳 $\Rightarrow$ 名瀬 (KNU) & 0.342 & -2.379 & 0.391 & -2.900 \\
\hline 和泊 $\Rightarrow$ 亀徳 (WKU) & 0.395 & -3.020 & 0.460 & -3.722 \\
\hline 与論 $\Rightarrow$ 和泊 (YWU) & 0.400 & -3.081 & 0.450 & -3.577 \\
\hline 本部 $\Rightarrow$ 与論 $(\mathrm{MYU})$ & 0.342 & -2.409 & 0.460 & -3.753 \\
\hline 那覇 $\Rightarrow$ 本部 (NMU) & 0.267 & -1.541 & 0.402 & -3.053 \\
\hline
\end{tabular}

“フェリー波之上”と“フェリーあけぼの”の航路毎の燃料消費 量を求め, 空気潤滑システムの省エネ効果を評価する。

プロペラ速度の平均值 $\bar{V}_{p 0}$ を計算し, Table 3 から航路毎に 対応する係数を選択して, (2) 式に代入すると両船の燃料消費 量を得る。

省エネ効果の評価は, 空気潤滑システムを搭載していない “フェリーあけぼの”の燃料消費量を比較のベースにするので, 得られた燃料消費量を, “フェリーあけぼの” 鹿児島-那覇間 (上り下り別) の燃料消費量で除した無次元值 $\left(F O C^{\prime}\right)$ にして Table 4 に示す。

鹿児島-那覇 (下り便) 間では, “フェリー波之上”の燃料消 費量が “フェリーあけぼの”に対して，0.952 倍となっている ことから, 空気潤滑システムによる省エネ効果 (Gross) は, 4.8\%(=1-0.952) である。同様に, 那覇一鹿児島 (上り便) の省 エネ効果も $4.8 \%$ となり, 上下便で同等の省エネ効果が得られ ている。

なお，ここで示した省エネ効果は，ブロワで船底に空気を 送り込む際に消費する電動機のエネルギーを考慮する前の, 全 体の省エネ効果 (Gross) である。

\section{(5) 実運航時の正味省エネ評価}

空気潤滑システムの使用時には，ブロワーで船底に空気を 送り込むために電力を使っており，主機関の然費から求めた省 エネ効果 (Gross) に対して, この電動機の電力消費分を含め て評価を行う必要がある。

そこで, ブロワー用電動機の消費電力に対する燃料消費量 を求めるために，まず “フェリー波之上”の総発電量と発電機 で消費された燃料流量の関係を, Fig.19に示す。図より両者 には強い相関関係 $(\mathrm{R}=0.996)$ が認められ, 一次近似式で表す とその傾きは 0.2214 であった。 
Table 4 Fuel oil consumption and propeller speed for each route

\begin{tabular}{l|cc|cc}
\hline 航路 & \multicolumn{2}{|c|}{ フェリー波之上 } & \multicolumn{2}{c}{ フェリーあけぼの } \\
\cline { 2 - 5 } & $\bar{V}_{p 0}$ & $F O C^{\prime}$ & $\bar{V}_{p 0}$ & $F O C^{\prime}$ \\
\hline \hline 鹿児島 $\Rightarrow$ 名瀬 $(\mathrm{KND})$ & 12.007 & 0.939 & 12.167 & 0.979 \\
名瀬 $\Rightarrow$ 亀徳 $(\mathrm{NKD})$ & 12.170 & 0.980 & 12.334 & 1.036 \\
亀徳 $\Rightarrow$ 和泊 $(\mathrm{KWD})$ & 12.041 & 0.961 & 12.197 & 1.017 \\
和泊 $\Rightarrow$ 与論 $(\mathrm{WYD})$ & 12.027 & 0.946 & 12.137 & 0.994 \\
与論 $\Rightarrow$ 本部 $(\mathrm{YMD)}$ & 12.144 & 0.954 & 12.278 & 1.005 \\
本部 $\Rightarrow$ 那覇 $(\mathrm{MND})$ & 12.151 & 0.932 & 12.139 & 0.969 \\
\hline 鹿児島 $\Rightarrow$ 那覇 $($ 下り) & & 0.952 & & 1.000 \\
\hline \hline 名瀬 $\Rightarrow$ 鹿児島 $(\mathrm{NKU)}$ & 11.976 & 0.963 & 12.092 & 1.011 \\
亀徳 $\Rightarrow$ 名瀬 $(\mathrm{KNU})$ & 12.091 & 0.977 & 12.088 & 1.028 \\
和泊 $\Rightarrow$ 亀徳 $(\mathrm{WKU)}$ & 12.040 & 0.981 & 11.983 & 1.013 \\
与論 $\Rightarrow$ 和泊 $(\mathrm{YWU)}$ & 11.938 & 0.936 & 11.794 & 0.974 \\
本部 $\Rightarrow$ 与論 $(\mathrm{MYU})$ & 12.036 & 0.943 & 12.047 & 1.012 \\
那覇 $\Rightarrow$ 本部 $(\mathrm{NMU)}$ & 11.981 & 0.911 & 11.829 & 0.962 \\
\hline 那覇 $\Rightarrow$ 鹿児島 $($ 上り) & \multicolumn{5}{|c|}{0.952} & 1.000 \\
\hline \hline
\end{tabular}

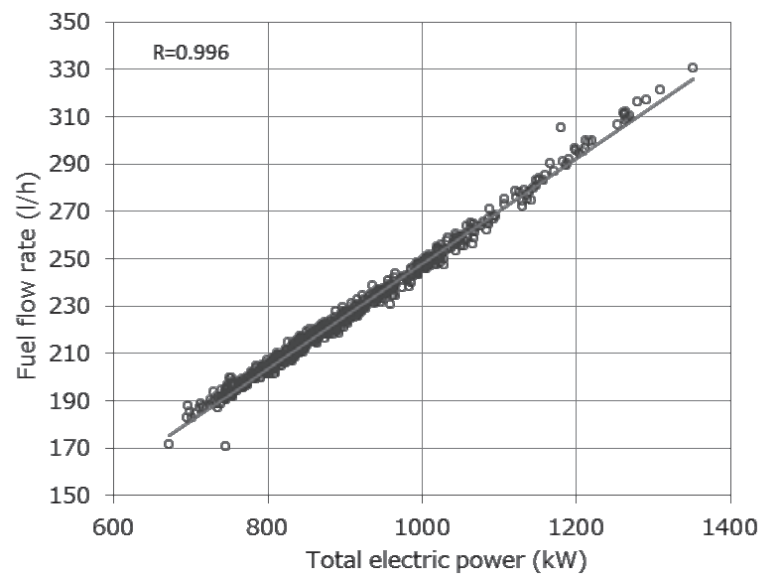

Fig. 19 Relation between total electoric power and fuel flow rate

ここで，解析対象期間のブロワ用電動機の消費電力の平均 值を求め, 近似直線の傾きを乗じると, ブロワ用電動機で消費 された燃料量がわかる。これを, 鹿児島一那覇間の“フェリー あけぼの”の主機関の平均燃費で除して無次元值を求めると, $1.67 \%$ がブロワの燃料消費量に相当する。

したがって，空気潤滑システムの実運航時にける正味省エ ネ効果 (Net) は, Gross の省エネ効果からブロワの燃料消費 分を差し引くと, 鹿児島-沖縄 (往復) で, $3.13 \%$ (=4.8-1.67) となった。

海上公試で確認された省エネ効果よりも值が小さくなった 要因の一つは， $\mathrm{NOx}$ 規制対策による“フェリー波之上”の主 機燃費の悪化によるもので, その他, 波浪, 潮流, 風などの海
象影響があるものと考えられる。

\section{5. 結 言}

本論文では，瘦せ型船に空気潤滑システムを適用し，その 省エネ効果を海上試運転時に実施した速力確認試験と就航後の 運航データの解析結果から検証する事を目的とした。検証結果 を以下にまとめる。

- 海上試運転において速力確認試験を実施して空気潤滑効 果を検証した結果, 主機出力の減少分からブロワの消費 電力を差し引いた正味の省エネ効果 (Net) は約 $3.7 \%$ で あった。

・プロペラディスク面へ気泡の流入によってプロペラ変動 圧が出力の大きさに関わらず約 1.4 倍増加していた。一 方, 船体振動についてはいずれの計測場所においても低 減しており, 空気潤滑による船体振動への悪影響はなく, むしろフェリーなどの乗客を運ぶ船にとっては大きなメ リットであると評価することができる。

・ 本船の就航後に長期間の運航モニタリングを実施して, 省 エネ効果を検証した。システムを搭載していない同型姉 妹船を比較対象として評価した結果，正味の省エネ効果 (Net) は $3.13 \%$ となった。ただし，“フェリー波之上”の 主機は NOx 規制対応のため姉妹船に対して約 $3 \%$ 燃費が 悪化している。

\section{謝 辞}

本研究の実施に際し，マルエーフェリー株式会社ならびに (独) 鉄道建設・運輸施設整備支援機構にはご理解と多大なご 協力を頂いた。なお，本研究の一部は，(一財) 日本海事協会 の支援を受けて実施したものである。ここに記し，深く感謝の 意を表する。

\section{参 考 文 献}

1) McComick, M. and Bhattacharyya, R.: "Drag Reduction of a Submersible Hull by Electrolysis", American Society of Naval Engineers Joural, pp.11-16, 1973

2) Kato, H., Miyanaga, M., Yamaguchi, H., and Guin M.M. : "Frictional Drag Reduction by Injecting Bubbly Water into Turbulent Boundary Layer", Cavitation and Gas Liquid Flow in Fluid Machinery and Devices, FED-Vol.190, ASME, pp.185-194, 1994

3) Kato, H. Iwashina, T., Miyanaga, M. and Yamaguchi, H. : "Effect of Microbubble Cluster on Turbulent Flow Structure" , IUTAM Symposium on Mechanics of Passive and Active Flow Control, Gottingen, pp.255-260, 1998 
4) Guin, M.M., Kato, H., Yamaguchi, H., Maeda, M. and Miyanaga, M. : "Reduction of Skin Friction by Microbubbies and its Relation with Near-Wall Bubble Concentration in a Channel", J. of Marine Science and Technology, vol.1, No.5, PP.241-254, 1996

5) Yoshida, Y., Takahashi, Y., Kato, H. and Guin, M.M. : "Distribution of void fraction in bubbly flow through a horizontal channel: Bubbly boundary layer flow, 2nd report", J. of Marine Science Technology, Vol.3, pp.3036,1998

6）児玉 良明, 角川 明, 石川 暁, 川北千春, 金井 健, 戸田 保幸, 加藤 洋治, 池本 晶彦, 山下 和春, 永松 哲郎: “青雲丸を用 いたマイクロバブルの摩擦抵抗低減実船実験一前編：準備 研究一”, 日本造船学会論文集, 第 192 号, pp.1-13., 2002

7）永松 哲朗, 児玉 良明, 角川 明, 高井 通雄, 村上 恭二, 石川 暁, 上入佐 光, 荻原 誠功, 吉田 有希, 鈴木 敏夫, 戸田 保 幸, 加藤 洋治, 池本 晶彦, 山谷 周二, 芋生 秀作, 山下 和 春: “青雲丸を用いたマイクロバブルの摩擦抵抗低減実船 実験一後編: 実船実験一”, 日本造船学会論文集, 第 192 号, pp.15-28. , 2002

8) 日夏宗彦, 児玉 良明, 堀利文, 川島 英幹, 竹子 春弥, 牧 野雅彦, 大縄 将史, 眞田 有吾, 村井 祐一, 太田 翔子: “大 型セメント運搬船を用いた空気潤滑法による省エネ実船実 験 (準備) ”, 日本船舶海洋工学会講演会論文集, 第 6 号, pp.161-162, 2008
9) 児玉 良明, 日夏 宗彦, 堀利文, 川島 英幹, 竹子 春弥, 牧野 雅彦, 大縄 将史, 眞田 有吾, 村井 祐一, 太田 翔子: “大型 セメント運搬船を用いた空気潤滑法による省エネ実船実験 （結果と解析）”, 日本船舶海洋工学会講演会論文集, 第 6 号, pp.163-166, 2008

10）溝上宗二, 川北千春, 小段洋一郎, 高野真一, 日笠靖司郎, 重永亮介: “空気潤滑システムの開発と実船試験による検 証”, 日本船舶海洋工学会論文集, 第 12 号, pp.69-77, 2010

11) 川島 久宜, 日夏 宗彦, 堀利文, 牧野 雅彦, 竹子 春弥: “空 気潤滑法における抵抗低減効果の速度影響”, 日本船舶海洋 工学会秋季講演会論文集, 第 9E 号, pp.93-96, 2009

12）日夏宗彦, 右近良孝, 堀利文, 久米健一, 児玉良明, 川村隆 文, 前田正二: “気泡流中を作動するプロペラが誘起する変動 圧力”, 日本船舶海洋工学会講演論文集, 第 8 号, pp.305-308, 2009

13）川北千春, 高野真一, 小段 洋一郎, 溝上 宗二: “船底に放 出した空気の挙動およびプロペラに及ぼす影響の模型試験に よる評価”, 日本船舶海洋工学会論文集, 第 12 号, pp.33-41, 2010 